\title{
Study of proteolysis in river buffalo mozzarella cheese using a proteomics approach
}

\author{
G. Petrella, ${ }^{*}$ S. Pati, ${ }^{*}$ R. Gagliardi,† A. Rizzuti, $\ddagger$ P. Mastrorilli, $\ddagger$ B. la Gatta, ${ }^{*}$ and A. Di Luccia*1 \\ *Dipartimento di Scienze Agrarie, degli Alimenti e dell'Ambiente, Università di Foggia, 71122 Foggia, Italy \\ †lstituto Zooprofilattico Sperimentale del Mezzogiorno, 80055 Portici (NA), Italy \\ ‡Dipartimento di Ingegneria Civile, Ambientale, del Territorio Edile e di Chimica (DICATECh), Politecnico di Bari via Orabona 4, 70125 Bari, Italy
}

\begin{abstract}
The guarantee of the origin and quality of raw material is essential for the protection and valorization of Campana buffalo mozzarella cheese. The risk of utilization of semifinished products and stored milk in substitution for fresh milk is increasing, due to the continuous desire to reduce production costs. A proteomics approach and electrophoresis survey of retail mozzarella cheeses indicated different rates of proteolysis in the production of dairy industries. The use of fresh milk and correct cheesemaking protocol yielded only $\gamma$-caseins, which are derived from $\beta$-casein by plasmin, and para- $\kappa$-casein, which is derived from $\kappa$-casein by chymosin. The detection of abnormal

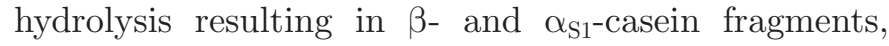
identified by mass spectrometry, indicates the use of stored milk or stored and pressed curd, or the reuse of unsold mozzarella cheese, to produce mozzarella. The formation of $\gamma$-caseins and other fragments during a long storage of raw materials at room or refrigeration temperature was ascribed to plasmin (endogenous milk enzyme), whereas formation of $\alpha_{\mathrm{S}_{1}}$-casein fragments, mainly $\alpha_{S 1}-I^{6 \mathrm{P}}$ - and $\alpha_{S_{1}}-\mathrm{I}^{7 \mathrm{P}}$-casein during the storage of curd was ascribed to the action of chymosin (exogenous enzyme) from rennet. Sodium dodecyl sulfate-PAGE and alkaline urea-PAGE permitted us to evaluate the freshness of the raw materials used in the manufacturing of buffalo mozzarella cheese and to reveal possible inappropriate preservation.
\end{abstract}

Key words: mozzarella, curd freshness, primary proteolysis, proteomic approach, molecular marker

\section{INTRODUCTION}

Campana buffalo mozzarella cheese is a Protected Designation of Origin (PDO) product registered under

Received April 22, 2015

Accepted July 27, 2015.

${ }^{1}$ Corresponding author: aldo.diluccia@unifg.it
Commission Regulation (EC) no. 1107/1996. According to the regulations, PDO buffalo mozzarella must be produced with whole, fresh river buffalo milk, coming from river buffalo reared in geographical areas given by the PDO specification; its unique characteristics are attributable to both the raw material and to the production technology. In recent years, price-based competition has led many dairies to lower production costs by choosing technological solutions that are not compatible with the typical product characteristics, such as the use of semi-manufactured materials in substitution for fresh milk. On the other hand, consumers cannot choose between a mozzarella produced from fresh milk and one produced from semi-manufactured materials, as the EU regulation no. 1107/1996 does not allow the use of semi-finished products. This undoubtedly creates unfair competition for conventional producers; therefore, dairy operators are increasingly interested in finding solutions to safeguard product typicality. An important phenomenon that occurs during cheese manufacture is proteolysis, which is due to the action of endogenous milk enzymes as well as that of rennet and microbial enzymes. In fresh cheese, such as mozzarella, mainly primary proteolysis is expected. Therefore, enzymatic protein fragmentation can be an effective way to control the preservation state of dairy products, because product history can be reconstructed from proteolysis levels and the formation of specific fragments (Fox, 1989; Mc Sweeney et al., 1993; Gaiaschi et al., 2000). Proteolysis in cheese (Fox and McSweeney, 1996) is produced by endo- and exopeptidases of different origins: plasmin, which is derived from milk; pepsin and chymosin, which are derived from rennet; as well as indigenous and starter microflora enzymes.

Plasmin is active on all caseins, but especially on $\beta$-CN (Eigel et al., 1984; Fox et al., 1994) and $\alpha_{S_{2}-} \mathrm{CN}$ (Le Bars and Gripon, 1989); its primary cleavage sites in $\beta$-CN are $\mathrm{Lys}_{28}-\mathrm{Lys}_{29}, \mathrm{Lys}_{105}-\mathrm{His}_{106}$, and $\mathrm{Lys}_{107}-\mathrm{Glu}_{108}$, with the formation of the fragments $\beta$-CN f29-209 $\left(\gamma_{1}-\mathbf{C N}\right)$, f106-209 $\left(\gamma_{2}\right.$-CN $)$, and f108-209 $\left(\gamma_{3}-\mathbf{C N}\right)$. $\gamma$-Casein fragments have been proposed as markers of Grana Padano cheese ripening (Gaiaschi et al., 2000). 
Chymosin is the main enzyme responsible for the primary proteolysis in most cheese varieties. This aspartyl protease is contained in the rennet together with pepsin; the main target of chymosin is peptide bond $\mathrm{Phe}_{105}-\mathrm{Met}_{106}$ of the $\mathrm{k}$-CN fraction, cleavage of which determines milk coagulation and curd formation. Chymosin is active also on both $\alpha_{\mathrm{S1}^{-}} \mathrm{CN}$ and $\beta$ - $\mathrm{CN}$ in solution (Carles and Ribadeau-Dumas, 1984) but in cheese it appears to hydrolyze mainly $\alpha_{\mathrm{S}_{1}} \mathrm{CN}$ (Fox, 1989; McSweeney et al., 1993; Mulvihill and McCarthy, 1993; Scherze et al., 1994; Sienkiewicz et al., 1994). The primary site of chymosin action on $\alpha_{s_{1}}-\mathrm{CN}$ is $\mathrm{Phe}_{23}-\mathrm{Phe}_{24}$, yielding the fragment $\alpha_{\mathrm{S} 1}-\mathrm{I}-\mathrm{CN} \mathrm{f}(24-199)$ (Hill et al., 1974; Carles and Ribadeau-Dumas, 1985; McSweeney et al., 1993); cleavage of the $\mathrm{Phe}_{23}-\mathrm{Phe}_{24}$ bond is believed to be responsible for softening of cheese texture (De Jong, 1976; Creamer and Olson, 1982). Faccia et al. (2014) reported that quantification of the fragment $\alpha_{\mathrm{S1}} \mathrm{I}-\mathrm{CN}$ can be effective for revealing the use of stored curd in high-moisture cow mozzarella because chymosin is denatured by the high temperature $\left(90^{\circ} \mathrm{C}\right)$ used during the stretching phases, it results in a low level of $\alpha_{\mathrm{SI}^{-}} \mathrm{CN}$ hydrolysis (Hayes et al., 2002; Sheehan et al., 2007; Faccia et al., 2014).

Chymosin also cleaves $\alpha_{s_{1}}$-casein at $\mathrm{Phe}_{28}-\mathrm{Phe}_{29}$, $\mathrm{Leu}_{40}-\mathrm{Ser}_{41}, \mathrm{Leu}_{149}-\mathrm{Phe}_{150}, \mathrm{Phe}_{153}-\mathrm{Tyr}_{154}, \mathrm{Leu}_{156}-\mathrm{Asp}_{157}$, Tyr $_{159}$-Pro $_{160}$, Try $164-$ Tyr165, Leu11-Pro $_{12}, \mathrm{Phe}_{32}-\mathrm{Gly}_{33}$, $\mathrm{Leu}_{101}-\mathrm{Lys}_{102}, \mathrm{Leu}_{142}-\mathrm{Ala}_{143}$, and $\mathrm{Phe}_{179} \mathrm{Ser}_{180}$, with the cleavage rate depending on the ionic strength and $\mathrm{pH}$ (Mulvihill and Fox, 1979; McSweeney et al., 1993). Finally, starter bacteria enzymes are known to affect secondary proteolysis (Yun et al., 1995; Gagnaire et al., 2004).

Primary proteolysis in mozzarella cheese is due to the incomplete thermal inactivation of enzymes during the stretching process (Richardson, 1983; McGoldrick and Fox, 1999); the production of $\alpha_{\mathrm{S}_{1}}-\mathrm{I}-\mathrm{CN}$ takes place in the earliest stages of production and proceeds at a rate that depends on curd cooking temperature and water activity (Tunick et al. 1993; Yun et al., 1993), on the amount of the residual rennet (Dave et al. 2003), as well as on $\mathrm{pH}$ and $\mathrm{NaCl}$ concentration (Feeney et al., 2002). Even though the primary proteolysis rate can be affected by several factors, it progresses quite slowly in both low- and high-moisture mozzarella (Kindstedt et al., 1988; Tunick et al., 1993; Faccia et al., 2014).

River buffalo milk proteins are analogous to bovine $\alpha_{S^{-}}$and $\beta$-CN. However, caseins from the 2 species are not identical because of small differences in primary structure (Addeo and Mercier 1977; Chikuni et al., 1995; Ferranti et al., 1998; Sukla et al., 2006), which may differently affect the proteolysis of casein fractions (Ganguli et al., 1965; Di Luccia et al., 2009), milk clot- ting (El-Shibiny and Abd El-Salam, 1977), and proteolytic enzymes from the 2 species.

Trieu-Cuot and Addeo (1981) reported the formation of a fragment, named compound $\mathrm{B}$, produced in river buffalo milk by the action of plasmin on $\beta-\mathrm{CN}$, which was identified by Di Luccia et al. (2009) as a fourth fragment originating from the presence of a plasminsensitive Lys bond at position 68 that is not present in bovine milk. The presence of $\beta-\mathrm{CN} \mathrm{f}(68-209)$, or $\gamma_{4}$-CN, in river buffalo milk was also reported by Somma et al. (2008). Furthermore, Di Luccia et al. (2009) established that this fragment was produced during the first fragmentation of $\beta-\mathrm{CN}$, unlike what occurs in bovine milk where $\gamma_{1}$ is the first fragment produced, and that $\gamma_{4}$ increases in refrigerated and frozen river buffalo milk and in curd and mozzarella cheese.

The long action of rennet involves the production of $\alpha_{\mathrm{SI}}$ fragments during storage of mozzarella cheese (Farkye et al., 1991; Di Matteo et al. (1982) estimated that about $55.4 \%$ of $\alpha_{\mathrm{Sl}}$ casein was hydrolyzed to $\alpha_{\mathrm{Sl}} \mathrm{I}$ and $\alpha_{\mathrm{SI}} \mathrm{II}$ peptides. In the same way, semi-finished products contain increased levels of $\alpha_{\mathrm{Sl}^{-}} \mathrm{I}$ and $\alpha_{\mathrm{Sl}} \mathrm{II}$ peptides in mozzarella cheese (Faccia et al., 2014); such products include pressed curds, which are produced by pressing curd into molds to remove most of the whey (Everard et al., 2011) to make their transport and storage easier.

As far as "Mozzarella di Bufala Campana" is concerned, no recent and sound scientific study to date has specifically assessed proteolysis. In this paper, we provide an overview on casein proteolysis of buffalo mozzarella to study the relationship between proteolysis and quality and to identify molecular markers of product freshness. The analytical techniques used for this work were 1- and 2-dimensional PAGE compined with detection by mass spectrometry and multivariate data analysis.

\section{MATERIALS AND METHODS}

\section{Reagents and Samples}

Acetonitrile, formic acid, tris(hydroxymethyl) aminomethane (Tris), $\mathrm{HCl}$, trichloroacetic acid, urea, dithiothreitol (DTT), bromophenol blue sodium salt, SDS, acrylamide/bis-acrylamide $30 \%$ solution $(37.5 \%$ $\mathrm{T} ; 1 \% \mathrm{C}$ ), ammonium bicarbonate phosphate, glycerol, iodoacetamide, acetone, Coomassie Brilliant Blue G (CBB), silver blue, and trypsin singles (Proteomics grade kit) were purchased from Sigma (St. Louis, MO) and used as received. DeStreak Rehydration Solution, immobiline DryStrip Cover Fluid, and bromophenol blue were from GE Healthcare Biosciences (Uppsala, 
Sweden); rennet with a strength of $1 / 10,000$ was bought at a local market.

Sixty samples of fresh PDO buffalo mozzarella, produced in Campania, were kindly furnished by Istituto Zooprofilattico (Portici, Napoli, Italy). Ten samples obtained from Campanian factories producing buffalo mozzarella under specific PDO requirements were used as control.

\section{SDS-PAGE Analysis}

Each sample $(0.10 \mathrm{~g})$ was solubilized in $1.0 \mathrm{~mL}$ of $9 M$ urea and an aliquot was added to a sample buffer containing Tris-HCl (0.6 M, pH 6.8), $2 \%$ SDS, $10 \%$ (vol/vol) glycerol, and $1.5 \%$ (wt/vol) DTT to obtain a final protein concentration of $4 \mathrm{mg} / \mathrm{mL}$. Then, $10 \mu \mathrm{L}$ of this solution was loaded on a $15 \%$ polyacrylamide pore gel $(1.5 \times 18 \times 16 \mathrm{~mm})$, and electrophoresis was carried out in a Hoefer SE 600 Series Ruby Standard Vertical Electrophoresis Unit (GE Healthcare BioSciences, Little Chalfont, UK), at $25 \mathrm{~mA}$ for $3 \mathrm{~h}$ at room temperature. The gels were stained with $0.25 \%$ (wt/ vol) CBB overnight (Candiano et al., 2004) and destained with water. Prestained SDS-PAGE standards (Bio-Rad, Richmond, CA) were used as protein molecular mass markers.

\section{Alkaline PAGE in the Presence of Urea}

Each sample $(0.10 \mathrm{~g})$ was dissolved in $1.0 \mathrm{~mL}$ of 9 $M$ urea. An accurate volume of solution $(100 \mu \mathrm{L})$ was mixed with $100 \mu \mathrm{L}$ of urea sample buffer (Tris-HCl, urea, traces of bromophenol blue sodium salt) containing $2 \%$ DTT. Duplicate samples $(7 \mu \mathrm{L})$ were loaded onto an $8-4 \%$ polyacrylamide gel $(1.5 \times 18 \times 16 \mathrm{~mm})$ in the presence of urea, using a Hoefer SE 600 Series Ruby Standard Vertical Electrophoresis Unit (GE Healthcare BioSciences). Urea-PAGE analysis was conducted as reported by Andrews (1983) and the gels were stained with $\mathrm{CBB}$ and destained in water. Image analysis was carried out using Quantity One software (Bio-Rad); the optical densities obtained were expressed as relative quantity compared with the total area of the identified bands in the electrophoretic pattern of each sample.

\section{Two-Dimensional Gel Electrophoresis}

Each sample $(0.10 \mathrm{~g})$ was mixed with $1.0 \mathrm{~mL}$ of $9 \mathrm{M}$ urea, and a $100-\mu \mathrm{L}$ aliquot was dissolved in $150 \mu \mathrm{L}$ of DeStreak Rehydration Solution and $100 \mathrm{~m} M$ DTT. The sample was hydrated with a $13-\mathrm{cm} \mathrm{pH} 3-10$ immobilized $\mathrm{pH}$ gradient (IPG) strip (Amersham Biosciences,
Melbourne, VIC, Australia) for a minimum of $8 \mathrm{~h}$ at room temperature. The first dimension was provided using an Ettan IPGphor 3 (GE Healthcare BioSciences) electrophoresis unit (Amersham Biosciences) in 4 steps: $500 \mathrm{~V} / \mathrm{h}$ followed by $1,000 \mathrm{~V} / \mathrm{h}$, a gradient to $8,000 \mathrm{~V}$ over $90 \mathrm{~min}$, and $8,000 \mathrm{~V}$ for $3 \mathrm{~h}$. After the IPG electrophoresis, the strips were equilibrated, first in a solution containing $1.5 \mathrm{M}$ Tris- $\mathrm{HCl}, \mathrm{pH} 6.8,6 \mathrm{M}$ urea, $30 \%$ glycerol (wt/vol), $2 \%$ SDS, $64 \mathrm{mM}$ DTT, and traces of bromophenol blue, for $15 \mathrm{~min}$, and then, in a solution containing 1.5 M Tris- $\mathrm{HCl}, \mathrm{pH}$ 6.8, $6 \mathrm{M}$ urea, $30 \%$ glycerol (wt/vol), $2 \%$ SDS, $135 \mathrm{~m} M$ iodoacetamide, and traces of bromophenol blue, for a further $15 \mathrm{~min}$. The equilibrated IPG dry strips were loaded on top of the $8-18 \%$ SDS-PAGE gradient polyacrylamide gel $(1.5 \times 18 \times 16 \mathrm{~mm})$, embedded with $1 \%$ agarose. The electrophoresis was carried out in an Hoefer SE 600 Series Ruby Standard Vertical Electrophoresis Unit (GE Healthcare BioSciences) at a constant voltage of $100 \mathrm{~V}$, at $30 \mathrm{~mA} / \mathrm{gel}$, for $16 \mathrm{~h}$ at $15^{\circ} \mathrm{C}$. Gels were stained with $0.25 \%$ (wt/vol) CBB overnight and destained in water. Images were captured on an ImageMaster Scanner (GE Healthcare BioSciences) in transmission mode, at a resolution of $300 \mathrm{dpi}$.

\section{Proteolysis of Buffalo Milk $\alpha_{s 1}$-Casein by Rennet}

$\alpha_{S_{1}}$-Casein, purified according to Di Luccia et al. (2009), was hydrolyzed by using rennet (strength of $1 / 10,000)$ and purified $\alpha_{S 1}$-casein at an enzyme:protein ratio of $1 / 500$ (wt/wt) in $50 \mathrm{~m} M$ phosphate buffer (pH 6) at $32^{\circ} \mathrm{C}$. The final concentration of $\alpha_{S 1}$-casein was 15 $\mathrm{mg} / \mathrm{mL}$. Aliquots were taken for analysis at 15, 30, 60, and $120 \mathrm{~min}$, and the reaction was stopped by dilution with a $24 \%$ trichloroacetic acid solution. Samples were then centrifuged at $12,000 \times g$ for $10 \mathrm{~min}$ at $4^{\circ} \mathrm{C}$; the pellet washed 3 times with cold acetone, dissolved in $1.0 \mathrm{~mL}$ of $9 M$ urea, and analyzed by alkaline urea PAGE as described above.

\section{In-Gel Digests}

Protein spots from 2-dimensional gel electrophoresis (2D-PAGE) were excised and an in situ digestion was applied. Spots were destained with a $25 \mathrm{mM}$ ammonium bicarbonate: $50 \%$ acetonitrile solution, reduced in a solution of $10 \mathrm{~m} M$ DTT:25 $\mathrm{m} M$ ammonium bicarbonate for $1 \mathrm{~h}$ at $56^{\circ} \mathrm{C}$, and alkylated by carboxymethylation in a $55 \mathrm{~m} M$ iodoacetamide and $25 \mathrm{mM}$ ammonium bicarbonate solution for $45 \mathrm{~min}$, in the dark. Then, protein spots were washed with a $25 \mathrm{mM}$ ammonium bicarbonate:50\% acetonitrile solution and digested in situ 
by trypsin at $37^{\circ} \mathrm{C}$ overnight. The peptides resulting from the digestion step were extracted 3 times with 40 $\mu \mathrm{L}$ of water:acetonitrile:formic acid solution (50:45:5, $\mathrm{vol} / \mathrm{vol} / \mathrm{vol}$ ) and then dried by vacuum centrifugation. Finally, the peptide mixtures were dissolved in water:acetonitrile $(50: 50, \mathrm{vol} / \mathrm{vol})$.

\section{Liquid Chromatography/Electrospray Ionization- Tandem Mass Spectrometry}

The HPLC-MS system adopted in this work consisted of an HPLC 1200 Series system (Agilent Technologies, Palo Alto, CA), equipped with a vacuum degasser (G1322A, Agilent), an autosampler (G1377A, Agilent), a quaternary pump, and a thermostatically controlled column compartment. The chromatographic separation was obtained with a Zorbax SB-C18 column $(2.1 \times$ $100 \mathrm{~mm}$ i.d., $1.8 \mathrm{~m}$ packing; Agilent) protected by a guard cartridge of the same packing, and maintained at $25^{\circ} \mathrm{C}$. The HPLC device was connected online to a MicrOTOF-Q II mass spectrometer (Bruker Daltonik GmbH, Bremen, Germany) equipped with an electrospray ionization source (ESI). The injection volume of the samples was $15 \mu \mathrm{L}$. The mobile phase, consisting of water with formic acid $(0.1 \%$; A) and acetonitrile with formic acid $(0.1 \%$; B), was pumped at $0.2 \mathrm{~mL} /$ min into the HPLC system with the following gradient elution program: $0-3 \mathrm{~min}$, isocratic $5 \% \mathrm{~B} ; 3-33 \mathrm{~min}$, linear from 5 to $50 \% \mathrm{~B}$; $33-38 \mathrm{~min}$, isocratic $50 \% \mathrm{~B}$; 20-21 min, linear from 95 to $5 \%$ B; 21-25 min, isocratic $5 \% \mathrm{~B}$, followed by column washing and re-equilibration

The time-of-flight (TOF) detector, used for accurate mass measurements, operated in positive mode (nebulizer gas, nitrogen, 1 bar; dry gas, nitrogen, $6.5 \mathrm{~L} / \mathrm{min}$, $200^{\circ} \mathrm{C}$; endplate offset $-500 \mathrm{~V}$; capillary voltage -4.5 $\mathrm{kV}$ ). External calibrations were made using a 100-L KD Scientific (Holliston, MA) syringe pump with a reference solution made up of $10 \mu \mathrm{L}$ of formic acid (98\%), $10 \mu \mathrm{L}$ of aqueous sodium hydroxide $(1.0 \mathrm{M}), 490 \mu \mathrm{L}$ of isopropanol and $490 \mu \mathrm{L}$ of deionized water. The rawfile data were collected as continuum mass spectrum at a regular time interval. Typically, 2 runs were performed for the HPLC-ESI-MS analysis of each sample. First, an MS full-scan acquisition (spectral rate of 1 spectrum/s with rolling averages of $3, \mathrm{~m} / z$ range of 100-2,000) was performed to obtain preliminary information on the predominant $m / z$ ratios observed during the elution. Then, the mass spectrometer was operated in data-dependent mode to automatically switch between MS and MS/MS acquisition selecting the 3 most abundant precursor ions. The tandem MS data were deconvoluted and deisotoped and exported in a generic Mascot format before database searching. Tandem MS search parameters had a mass accuracy of $0.025 \mathrm{Da}$ and carboxymethyl as constant modification.

Proteins were tentatively identified by peptide mass fingerprinting by mass searches in the database Swiss Prot (Swiss Institute of Bioinformatics, Geneva, Switzerland) or by fragmentation of their parent ions in MS/MS mode followed by mass searches in the Mascot database (Matrix Science, Boston, MA).

\section{Statistical Analysis}

The relative intensities of urea-PAGE bands were subjected to principal component analysis (PCA), excluding after a first screening all variables with scores $<0.5$. The data were analyzed with Statistica software package (version 7, StatSoft, Tulsa, OK).

\section{RESULTS AND DISCUSSION}

Proteolysis was investigated in 60 samples of PDO buffalo mozzarella cheese to highlight possible situations of fraud for consumers. As control, we considered 10 samples of PDO buffalo mozzarella cheese manufactured in controlled conditions. Information from SDSPAGE, 2D-PAGE, urea-PAGE, and MS were combined to obtain insight into proteolysis phenomena.

\section{Screening of Protein Profile of PDO Mozzarella Samples by SDS-PAGE}

Results of SDS-PAGE patterns that are representative of caseins from unknown PDO samples (lanes S1 to S5) and control (lane C1) mozzarella samples are shown in Figure 1. The estimated molecular weight (MW) of bands was calculated by using a Precision Plus Protein Dual Xtra Standard (Bio-Rad).

Although the separation of $\beta-\mathrm{CN}$ and $\alpha_{S^{-}} \mathrm{CN}$ fractions of river buffalo casein was very poor by SDS-PAGE, the bands from proteolysis fragmentation of parent caseins were well distinguished. Profiles of samples S1 and S3 were similar to those of the control, showing the expected presence of intense bands with estimated MW of $30-33 \mathrm{kDa}$ ascribable to $\beta-\mathrm{CN}$ and $\alpha_{\mathrm{S}^{-}} \mathrm{CN}$ fractions, a low-intensity band at $15 \mathrm{kDa}$, ascribable to $\beta$-CN f (69-209), named $\gamma 4$ according to Di Luccia et al. (2009), and a band at $13 \mathrm{kDa}$ corresponding to para-kCN. Unlike S3, samples S2, S4, and S5 showed numerous intense protein bands at low MW $(<25 \mathrm{kDa})$, which suggests secondary proteolytic activity. In particular, $\mathrm{S} 2$ showed a strong reduction of $\beta-\mathrm{CN}$ as well as the presence of low MW bands of high intensity and an additional intense band at an estimated MW of 17.5 
$\mathrm{kDa}$. This band could be due to the fragment $\alpha_{\mathrm{S} 1}-\mathrm{CN}$ $\mathrm{f}(35-199)$, which appears to be a proteolytic product obtained by plasmin digestion of $\alpha_{\mathrm{S1}^{-}} \mathrm{CN}$, identified by Gaiaschi et al. (2000) as $\alpha_{\mathrm{b}}$. However, the co-migration of a $\beta-C N$ fragment cannot be ruled out. The $\mathrm{S} 4$ lane also showed a strong reduction of $\beta$-CN but with lessintense bands at $\mathrm{MW}<25 \mathrm{kDa}$, suggesting a different proteolytic activity. It is interesting to note the disappearance of $\gamma 1$ and $\gamma 4$ and concomitant increase of $\gamma 2$ and $\gamma 3$ bands in S2 and S4, implying the occurrence of further proteolysis on $\gamma 1$ and $\gamma 4$ fragments. Finally, the protein pattern of S5 showed more $\beta-\mathrm{CN}$ than those of $\mathrm{S} 2$ and S4, even though it showed the presence of $\gamma 4$ together with the presence of low MW bands, as also seen in S2, suggesting a different level of enzymatic activity. Because it is possible to study only primary proteolysis by conventional monodimensional electrophoresis, our results on samples S2, S4, and S5 showed differences in migration and intensity of bands, suggesting the occurrence of a primary proteolysis activity at a different level. Thus, we submitted the most hydrolyzed sample, $\mathrm{S} 2$, and the least hydrolyzed sample, S1, to further 2DPAGE and MS investigations.

\section{D-PAGE and MS Investigation}

Separations by 2D-PAGE of S1 and S2 caseins are shown in Figures 2A and 2B, respectively. For S2, 29 protein spots could be detected compared with the 8 spots revealed for S1. For identification purposes, all gel spots were cut and digested with trypsin; tentative identifications, reported in Table 1, were achieved by combining information of ESI-quadrupole (Q)-TOF peptide mass fingerprints (MS full-scan data), ESIQ-TOF MS/MS analysis of some peptides, and spot position in terms of MW and isoelectric point (pI). The pI and MW were estimated by 2D-PAGE and by Protein Prospector database (http://prospector.ucsf. edu/prospector/mshome.htm) output when simulating peptide digestion. The latter approach is to be considered reliable if the investigated peptide is thought to have a few phosphorylations or other modifications. We assumed MW estimations herein to be theoretical MW (Table 1). The positions of the major caseins in the 2D-PAGE gels are indicated in Figure 2. Although S1 showed only a few spots easily ascribable to $\alpha_{\mathrm{S1}^{-}}$, $\alpha_{\mathrm{S}^{-}}, \beta-$, and para- $\kappa-\mathrm{CN}$ based on the literature and MS

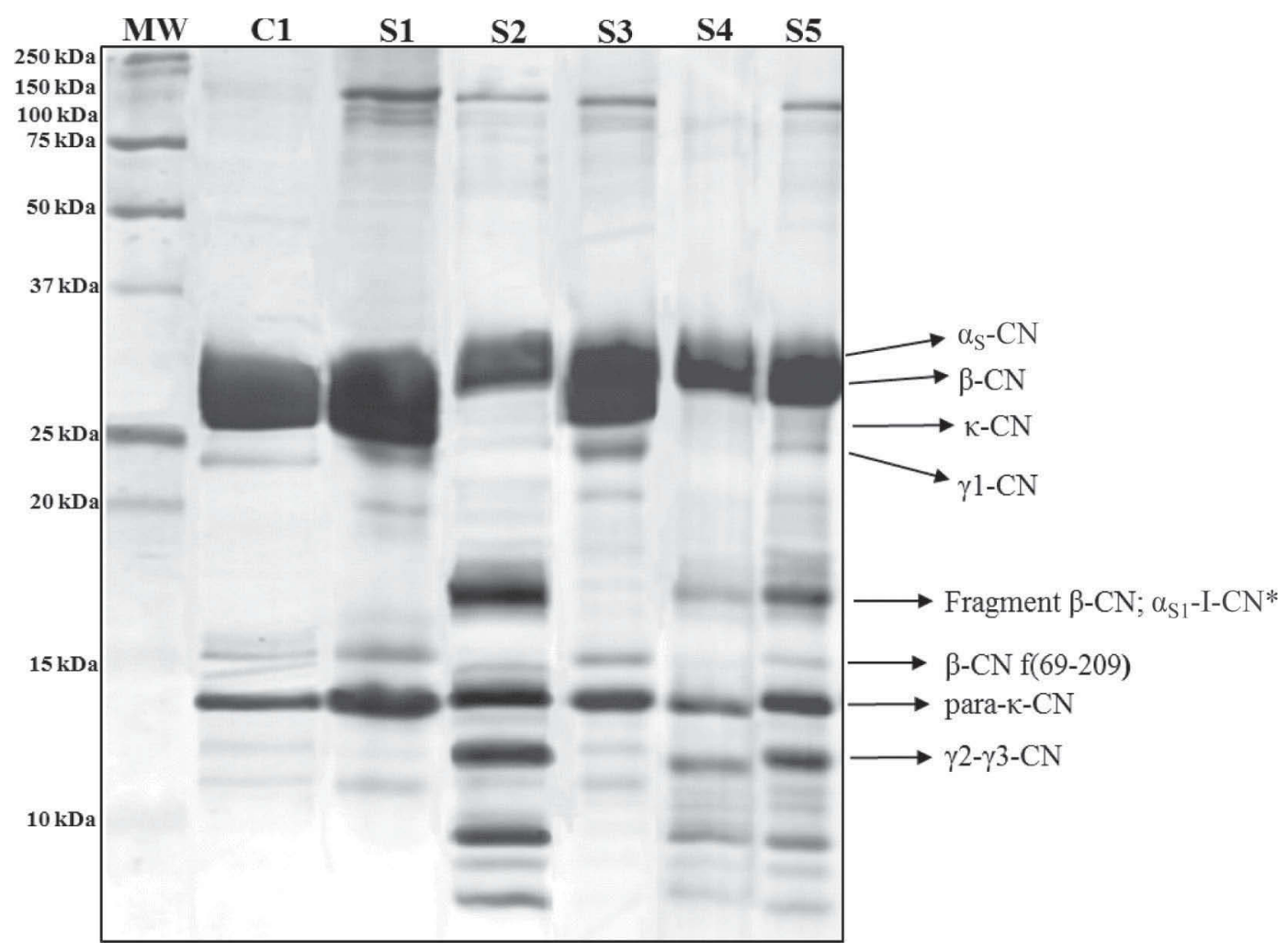

Figure 1. Sodium dodecyl sulfate-PAGE pattern of Protected Designation of Origin (PDO) buffalo mozzarella caseins. Lane MW = molecular mass standard; lane $\mathrm{C} 1$ = fresh PDO buffalo mozzarella caseins; lanes S1 to S5 = caseins of samples with different levels of proteolysis. Asterisk $(*)$ indicates tentative attribution based on the literature. 


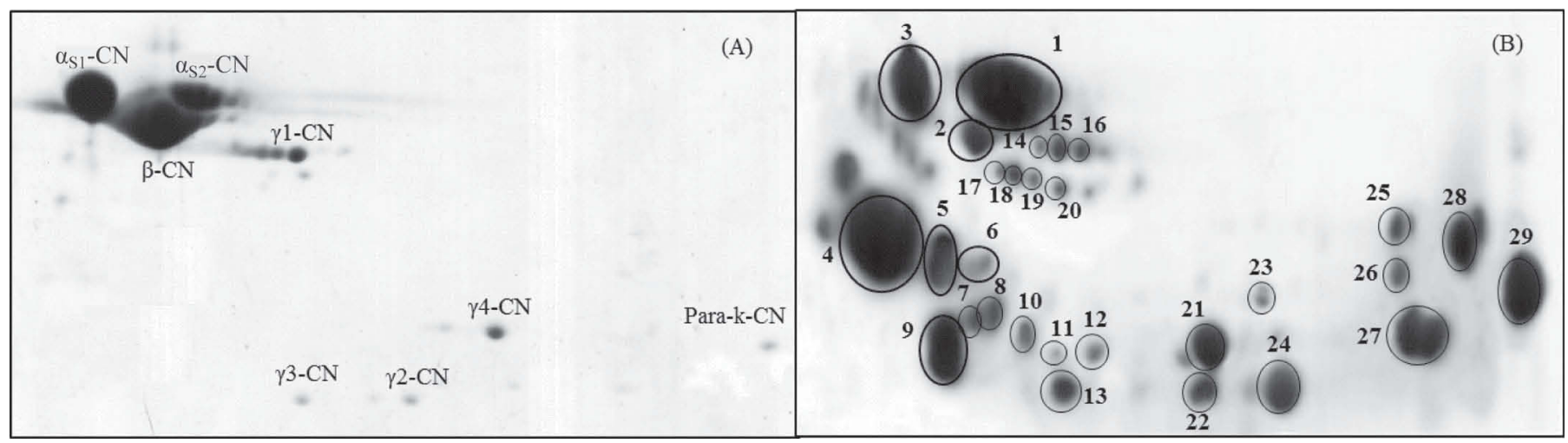

Figure 2. Two-dimensional PAGE of caseins from fresh Protected Designation of Origin buffalo mozzarella (A) and from the highly proteolysed sample 5 (B). Identification of the bands is reported in Table 1.

information, 2D-PAGE of S2 exhibited several spots at lower MW. Moreover, it is noteworthy that the $\alpha_{\mathrm{S}_{2}} \mathrm{CN}$ fractions in the S2 2D-PAGE map exhibited a higher content compared with $\alpha_{S 1}-\mathrm{CN}$ and, in agreement with the monodimensional SDS-PAGE, a marked diminution of $\beta$-CN fraction. This could indicate intense proteolysis due to plasmin during inappropriate storage of mozzarella cheese or due to the use of poor quality, semi-finished products.

Based on MS results, spots 4 to 13 were ascribed to $\alpha_{\mathrm{S}^{-}} \mathrm{CN}$ fragments. In particular, spot 4 was assigned to $\alpha_{\mathrm{S} 1}-\mathrm{I}-\mathrm{CN} \mathrm{f}(24-199)$, as that was the most intense band and, as expected, its estimated pI and MW were, respectively, more acidic and lower than that of $\alpha_{\mathrm{S}_{1}} \mathrm{CN}$. In analogy to bovine caseins, the $\alpha_{\mathrm{S} 1}-\mathrm{I}-\mathrm{CN}$ fragment appears to be the main proteolytic product obtained by rennet digestion of the parent casein fraction (Mulvihill and Fox, 1979; McSweeney et al., 1993). In cheesemaking, production of this large peptide has been closely associated with chymosin: in bovine mozzarella cheese, its formation is reported to occur at the earliest stage of production and to proceed at a rate that depends on cooking temperature and water activity (Tunick et al. 1993; Yun et al., 1993), amount of residual rennet (Dave et al. 2003), $\mathrm{pH}$ and $\mathrm{NaCl}$ concentration (Feeney et al., 2002). Faccia et al. (2014) found that $\alpha_{S 1}-\mathrm{I}-\mathrm{CN}$ appeared at a low level in fresh milk and increased with inappropriate conservation of milk. The formation of this fragment in the milk could be due to enzymes that recognize the same cleavage sites as chymosin, such as enzymes of psychrotrophic bacteria (Barry, 1979; Law et al., 1979) and cathepsin D. Enzymes from psychrotrophic bacteria represent a major spoilage factor of stored milk before processing (Sorhaug and Stepaniak 1997), and cathepsin D, an endogenous aspartic protease in milk, appears correlated with somatic cell count (Hurley et al. 2000). Other $\alpha_{\mathrm{S}^{-}} \mathrm{CN}$ fragments were found, suggesting an intense proteolytic activity likely related to the different ages of the curds used for production of the analyzed samples: the greater the age of the curd, the greater the presence of products of proteolysis, as has also been reported for bovine curds (Faccia et al., 2014).

Spot 5 matched well with $\alpha_{\mathrm{S}_{1}-\mathrm{CN}} \mathrm{f}(35-199)$, identified by Gaiaschi et al. (2000) as $\alpha_{b}$, and generated by plasmin. Moreover, the co-migration in the second dimension (SDS-PAGE) of spot 5 with spot 26, ascribed to $\beta$-CN fragments, supports our previous suggestion of co-migration of $\alpha_{\mathrm{S}_{1}}-\mathrm{CN}$ and $\beta$-CN fragments. Spot 9 matched well with $\alpha_{S_{1}-} \mathrm{CN} f(80-199)$, reported by Gaiaschi et al. (2000) as $\alpha_{c}$, and generated by plasmin; spot 21 was ascribed to $\beta-\mathrm{CN} f(78-209)$ with a theoretical pI and MW of 7.03 and 14,677; and spot 27, based on pI and MW, might be $\beta-\mathrm{CN} f(67-209)$ with a theoretical pI and MW of 8.57 and 14,392, and originating from the primary action of milk and bacterial acid proteinase (Kaminogawa et al., 1980; Juillard et al., 1995).

Spots 14 to 20 were attributed to fragments of $\alpha_{\mathrm{S2}^{-}}$ $\mathrm{CN}$ with a lower level of phosphorylation, being the fraction most subjected to phosphorylation during milk synthesis (Swaisgood, 1992; Mamone et al., 2003). Spot

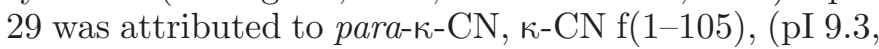
MW 12,366), based on a combination of MS and 2DPAGE data (pI 9.24, MW 14,500). By 2D-PAGE and monodimensional SDS-PAGE (see Figure 1), the MW of para- $\kappa-\mathrm{CN}$ was somewhat different from expected, probably because of an interaction of the protein with SDS. Moreover, the recognition of only 2 peptides belonging to $\kappa$-CN suggests that spot 29 could represent more than one protein.

Finally, spots 21 to 28 were attributed to fragments of $\beta$-CN, originating from plasmin activity, which 


\begin{tabular}{|c|c|c|c|c|c|c|c|}
\hline $\begin{array}{l}\text { Spot } \\
\text { number }\end{array}$ & $\begin{array}{l}2 \mathrm{D} \mathrm{pI} / \mathrm{MW} \\
\text { estimated }^{1}\end{array}$ & $\begin{array}{l}\text { PProspector } \\
\mathrm{pI} / \mathrm{MWth}^{2}\end{array}$ & $\begin{array}{c}\text { No. of } \\
\text { peptides } \\
\text { matching } \\
\text { protein }^{3}\end{array}$ & Peptides matching protein ${ }^{3}$ & $\begin{array}{l}\text { Coverage of } \\
\text { the matching } \\
\operatorname{protein}^{4}(\%)\end{array}$ & $\begin{array}{c}\text { No. of } \\
\text { matched } \\
\text { peptides } \\
\text { MS/MS }\end{array}$ & Accession number and name ${ }^{6}$ \\
\hline 1 & $5.09 / 23500$ & $6.4 / 24179$ & 13 & $\begin{array}{l}71-76 ; 81-91 ; 115-125 ; 126-136 ; 126-137 ; 137-149 ; \\
138-149 ; 138-150 ; 153-158 ; 161-165 ; 174-181 ; 182-188 \\
198-205\end{array}$ & 42.2 & $5(1)$ & 4584554 BUBALUS BUBALIS a $_{22}$-casein \\
\hline 2 & $4.84 / 22500$ & $5.1 / 23583$ & 5 & $29-32 ; 100-107 ; 170-176 ; 177-183 ; 203-209$ & 15.7 & $4(4)$ & Q9TSI0 O62824 CASB BUBBU \\
\hline 3 & $4.29 / 23000$ & $4.8 / 22773$ & 9 & $\begin{array}{l}37-58 ; 80-83 ; 84-90 ; 91-100 ; 91-102 ; 104-124 ; 125-132 \\
133-151 ; 194-199\end{array}$ & 49.5 & $5(1)$ & O62823 CASA1_BUBBU \\
\hline 4 & $4 / 20000$ & $4.5 / 20108$ & 8 & $\begin{array}{l}80-83 ; 84-90 ; 91-100 ; 103-124 ; 104-124 ; 125- \\
132 ; 133-151 ; 194-199\end{array}$ & 43.2 & $3(1)$ & $\begin{array}{l}\text { A }_{\text {S1-I-CN f }}(24-199) / O 62823 \text { CASA1_- } \\
\text { BUBBU }\end{array}$ \\
\hline 5 & $4.99 / 18900$ & $4.8 / 24369$ & 3 & $91-100 ; 104-124 ; 133-151$ & 24.5 & $3(3)$ & O62823 CASA1_BUBBU \\
\hline 6 & $4.89 / 18500$ & $4.8 / 24369$ & 2 & $84-90 ; 91-100$ & 8.5 & - & O62823 CASA1_BUBBU \\
\hline 7 & $4.79 / 14800$ & $4.8 / 24369$ & 7 & $\begin{array}{l}59-79 ; 84-90 ; 91-100 ; 104-124 ; 125-132 ; 133-151 ; \\
194-199\end{array}$ & 46.0 & $2(2)$ & O62823 CASA1_BUBBU \\
\hline 8 & $4.98 / 14900$ & $4.8 / 24369$ & 8 & $\begin{array}{l}59-79 ; 80-83 ; 84-90 ; 91-100 ; 104-124 ; 125-132 ; 133- \\
151 ; 194-199\end{array}$ & 48.0 & $3(3)$ & O62823 CASA1_BUBBU \\
\hline 9 & $4.52 / 13500$ & $4.8 / 24369$ & 4 & $91-100 ; 125-132 ; 133-151 ; 194-199$ & 21.5 & $2(2)$ & O62823 CASA1_BUBBU \\
\hline 10 & $5.24 / 13800$ & $4.8 / 24369$ & 2 & $91-100 ; 104-124$ & 15.5 & - & O62823 CASA1_BUBBU \\
\hline 11 & $5.44 / 13500$ & $4.8 / 24369$ & 2 & $84-90 ; 91-100$ & 8.5 & - & O62823 CASA1_BUBBU \\
\hline 12 & $5.79 / 13700$ & $4.8 / 24369$ & 1 & $91-100$ & 5.0 & - & O62823 CASA1_BUBBU \\
\hline 13 & $5.50 / 11700$ & $4.8 / 24369$ & 1 & $91-100$ & 5.0 & - & O62823 CASA1_BUBBU \\
\hline 14 & $5.34 / 22300$ & $6.4 / 24800$ & 8 & $\begin{array}{l}\text { 71-76; 71-80; 81-91; 92-113; 115-125; 174-181; 182-- } \\
188 ; 198-205\end{array}$ & 37.9 & $2(2)$ & 4584554 BUBALUS BUBALIS $\mathrm{a}_{\mathrm{S} 2}$-casein \\
\hline 15 & $5.44 / 22300$ & $7.2 / 24800$ & 9 & $\begin{array}{l}71-76 ; 81-91 ; 92-113 ; 115-125 ; 153-158 ; 167-173 ; 174- \\
181 ; 182-188 ; 198-205\end{array}$ & 41.7 & $2(2)$ & 4584554 BUBALUS BUBALIS a $_{\mathbb{S}_{2} \text {-casein }}$ \\
\hline 16 & $5.69 / 22200$ & $7.2 / 24800$ & 11 & $\begin{array}{l}71-76 ; 81-91 ; 92-113 ; 115-125 ; 126-136 ; 153-158 ; 161- \\
165 ; 167-173 ; 174-181 ; 182-188 ; 198-205\end{array}$ & 50.5 & $2(2)$ & 4584554 BUBALUS BUBALIS $\mathrm{a}_{\mathrm{S} 2}$-casein \\
\hline 17 & $5.00 / 21500$ & $7.2 / 24800$ & 7 & $\begin{array}{l}71-76 ; 81-91 ; 92-113 ; 115-125 ; 153-158 ; 174-181 ; \\
182-188\end{array}$ & 34.5 & $2(2)$ & 4584554 BUBALUS BUBALIS $\mathrm{a}_{\mathrm{S2}}$-casein \\
\hline 18 & $5.14 / 21500$ & $7.2 / 24800$ & 11 & $\begin{array}{l}71-76 ; 71-80 ; 81-91 ; 92-113 ; 92-114 ; 115-125 ; 153-158 \\
167-173 ; 174-181 ; 182-188 ; 198-205\end{array}$ & 44.2 & $3(1)$ & 4584554 BUBALUS BUBALIS $\mathrm{a}_{\mathrm{S2}-\text {-casein }}$ \\
\hline 19 & $5.29 / 21500$ & $7.2 / 24800$ & 14 & $\begin{array}{l}71-76 ; 71-80 ; 81-91 ; 92-113 ; 114-125 ; 115-125 \\
126-136 ; 138-149 ; 153-158 ; 153-160 ; 167-173 ; 174-181 \\
182-188 ; 198-205\end{array}$ & 56.3 & $2(2)$ & 4584554 BUBALUS BUBALIS $\mathrm{a}_{\mathrm{S} 2}$-casein \\
\hline 20 & $5.45 / 21300$ & $7.2 / 24800$ & 8 & $\begin{array}{l}71-76 ; 81-91 ; 92-113 ; 115-125 ; 153-158 ; 174-181 \\
182-188 ; 198-205\end{array}$ & 38.8 & $2(2)$ & 4584554 BUBALUS BUBALIS $\mathrm{a}_{\mathrm{S2}^{2} \text {-casein }}$ \\
\hline 21 & $6.74 / 13500$ & $5.3 / 25107$ & 5 & $98-105 ; 170-176 ; 177-183 ; 184-202 ; 203-209$ & 22.8 & $2(2)$ & CASB BUBBU \\
\hline 22 & $6.73 / 11700$ & $5.5 / 11519$ & 3 & $170-176 ; 177-183 ; 203-209$ & 20.6 & $2(2)$ & $\mathrm{f}(108-209) / \mathrm{CASB}$ BUBBU \\
\hline 23 & $7.14 / 14000$ & $6.3 / 12412$ & 3 & $170-176 ; 177-183 ; 203-209$ & 18.9 & $2(2)$ & $\mathrm{f}(98-209) / \mathrm{CASB}$ BUBBU \\
\hline 24 & $7.29 / 12000$ & $6.3 / 11784$ & 4 & $170-176 ; 177-183 ; 184-202 ; 203-209$ & 38.5 & $2(2)$ & $\mathrm{f}(106-209) / \mathrm{CASB} B U B \mathrm{BU}$ \\
\hline 25 & $8.24 / 20500$ & $5.3 / 25107$ & 3 & $170-183 ; 184-202 ; 203-209$ & 19.0 & $1(1)$ & CASB BUBBU \\
\hline 26 & $8.24 / 14500$ & $6.8 / 15749$ & 3 & $170-176 ; 177-183 ; 203-209$ & 14.9 & $2(2)$ & $\mathrm{f}(69-209) / \mathrm{CASB}$ BUBBU \\
\hline 27 & $8.44 / 14000$ & $8.57 / 14392$ & 4 & $98-105 ; 170-176 ; 177-183 ; 203-209$ & 25.7 & $3(2)$ & $\mathrm{f}(67-209) / \mathrm{CASB}$ BUBBU \\
\hline 28 & $8.79 / 19000$ & $8.2 / 17968$ & 2 & $184-202 ; 203-209$ & 16.1 & $1(1)$ & f(49-209)/CASB BUBBU \\
\hline 29 & $9.24 / 14500$ & $9.3 / 12366$ & 2 & $11-16 ; 69-86$ & 22.6 & & $\begin{array}{l}\text { para-k-CN f(1-105)/P11840 CASK } \\
\text { BUBBU }\end{array}$ \\
\hline
\end{tabular}

${ }^{1}$ Apparent isolelectric point (pI) and molecular weight (MW) values estimated from 2-dimensional (2D)-PAGE. The pI values correspond to the middle of the spots.

${ }^{2} \mathrm{pI}$ and MW as estimated by Mascot/Protein Prospector databases (http://www.matrixscience.com/; http://prospector.ucsf.edu/prospector/mshome.htm); tentative identifications are shown in bold; pI and MW as estimated by Protein Prospector database output when simulating the peptide digestion.

${ }^{3}$ Number and peptides matching protein as resulted by Protein Prospector search with MS full-scan data as entry.

${ }^{4}$ Calculated as number of matched AA/total AA.

${ }^{5}$ Number and peptides matching protein as resulted by Mascot search with MS/MS data as entry; unique peptides are shown in parentheses.

${ }^{6}$ SwissProt database; for $\alpha_{\mathrm{S} 2}$ CN, NCBInr.2013.6.17 database (http://www.expasy.ch/sprot; http://www.ncbi.nlm.nih.gov). 
continues during cold storage and survives the hightemperature treatment during the processing of dairy products (Richardson, 1983b). The action of plasmin on lysine residues is well documented (Sherry et al., 1966), and it has been shown to produce $\gamma 1 \mathrm{f}(29-209)$, $\gamma 2 \mathrm{f}(106-209), \gamma 3 \mathrm{f}(108-209)$, and $\gamma 4 \mathrm{f}(69-209)$ (Eigel, 1977; Trieu-Cuot and Addeo, 1981). Thus, the majority of $\beta$-CN spots were tentatively attributed by simulating the cleavage of each Lys residue in $\beta-\mathrm{CN}$ and matching information of theoretical $\mathrm{pI}$ and $\mathrm{MW}$ with 2D-PAGE data. Spot 28 was assigned to $\mathrm{f}(49-209)$ (pI 8.2, MW 17,968), spot 27 to $\beta-\mathrm{CN} \mathrm{f}(67-209)$ (pI 8.57, MW 16,184), spot 26 to $\gamma 4 \mathrm{f}(69-209)$ (pI 6.8, MW $15,749)$, spot 23 to $\mathrm{f}(98-209)$ (pI 6.3, MW 12,412), spot 24 to $\gamma 2 \mathrm{f}(106-209)$ (pI 6.3, MW 11,784), and spot 22 to $\gamma 3 \mathrm{f}(108-209)$ (pI 5.5, MW 11,519). The fragments relevant to spots 21 and 25 could not be identified; due to chymosin action, other cleavage sites could be hypothesized.

Based on the above considerations, it was evident that sample S2 was severely proteolyzed; therefore, bands present in SDS-PAGE (Figure 1) were likely composed of more fragments coeluting together.

\section{Alkaline Urea-PAGE Analysis}

All samples were also analyzed by alkaline ureaPAGE, the most widely used electrophoretic technique to investigate primary proteolysis in cheese and which is able to reveal several large casein fragments (Ledford et al., 1966; Fox, 1989); in Figure 3, results from unknown PDO (lanes S1 to S5) and control (lane C1) mozzarella samples are shown. Sample C1 exhibited $\beta-\mathrm{CN}, \alpha_{\mathrm{S}_{2}}$ $\mathrm{CN}$, and $\alpha_{\mathrm{S}^{-}} \mathrm{CN}$ bands, faint bands of similar intensity in the area of $\gamma-\mathrm{CN}$, and no further band corresponding to peptides with higher negative net charge. $\alpha_{\mathrm{S}^{-}}$-Casein showed 2 major bands due to its heterogeneity for different degrees of phosphorylation and we named these $\alpha_{\mathrm{S} 1}-\mathrm{CN}^{6 \mathrm{P}}$ and $\alpha_{\mathrm{S}_{1}}-\mathrm{CN}^{7 \mathrm{P}}$ (Figure 3 ) according to the findings of Chianese et al. (2009). Samples S2 and S5 showed more intense and numerous bands at electrophoretic mobility of $\alpha_{\mathrm{S} 1}$ fragments and $\gamma$-CN with the exception of $\gamma 4$ and $\gamma 1$, which were reduced or disappeared, in agreement with MS data. The 2 major bands with the highest electrophoretic mobility, together with a reduction of $\beta$-CN and $\alpha_{\mathrm{S} 1}-\mathrm{CN}$ intensities, suggest the presence of intense primary proteolysis. Furthermore, it is worth noting the presence of an intense band that migrated between $\beta-\mathrm{CN}$ and $\alpha_{\mathrm{S} 1}-\mathrm{CN}$ fractions. This band could correspond to co-migrating fragments from $\beta$ - and $\alpha_{\mathrm{S}^{-}} \mathrm{CN}$ as deduced from $\mathrm{pI}$ of the 2D-PAGE map and identified by MS as spots 11, 12, 13, and 21 (Table 1).

The bands with the highest mobility, in analogy to cow mozzarella, could be similar to ALMI that was identified as $\alpha_{\mathrm{S} 1}-\mathrm{I}-\mathrm{CN}$ (Faccia et al., 2014). However, the river buffalo $\alpha_{S 1}-\mathrm{I}-\mathrm{CN}$ presented 2 bands that we named $\alpha_{\mathrm{S} 1} \mathrm{I}^{6 \mathrm{P}}$ and $\alpha_{\mathrm{S} 1} \mathrm{I}^{7 \mathrm{P}}$ based on their respective electrophoretic mobility deriving from parent protein (Figure 3). These could be derived by fragmentation of parent casein with different phosphorylation degree as shown by their heterogeneity (Figure 3 ). Bovine $\alpha_{\mathrm{S}^{-}}$ I-CN presented one band (Faccia et al., 2014), which increased very slowly in low-moisture mozzarella, and even though it could be detected in significant amounts after several week of ripening, it is present only in small amounts in fresh cheese (Sheehan et al., 2004; Costabel et al., 2007). Bovine $\alpha_{S_{1}}-\mathrm{I}-\mathrm{CN}$ is even less abundant in high-moisture cheese, and is barely detectable in cheeses aged for only a few days (Di Matteo et al., 1982; Baruzzi et al., 2012; Faccia et al., 2014). Unlike in fresh cow mozzarella, no $\alpha_{\mathrm{S}_{1}} \mathrm{CN}$ fragment was detected in fresh buffalo mozzarella samples, suggesting that chymosin action is slower (El-Shibiny and El-Salam, 1977; Gaiaschi et al., 2000; Bonfatti et al., 2013). Therefore, the $\alpha_{\mathrm{S} 1}$-I-CN fragments were detectable only in mozzarella cheese when the proteolysis occurred at much higher level, indicating poor milk preservation or the use of semi-manufactured curd; the intensity among the samples was different, probably due to the age and manufacturing or storage conditions.

Principal component analysis (Figure 4) was carried out, with the relative intensities of urea-PAGE bands relevant to all samples as variables (scores $>0.5$ ). Principal components (PC) 1 and PC2 accounted for 53.61 and $17.72 \%$ of total variance, respectively. On PC1, PCA discriminated samples according to proteolysis phenomena: samples with a low abundance of proteolysis products (group 1) showed negative high scores in the first component, whereas proteolyzed samples (group 2) had positive PC1 scores (Figure 4A). It is interesting to note that group 2 was not as homogeneous as group 1, although it was well separated from group 1 , likely reflecting the numerous causes of proteolysis. The most discriminant variables were the main caseins $\alpha_{\mathrm{S} 1}-\mathrm{CN}$ and $\beta-\mathrm{CN}$, which showed high scores for group 1 , and $\alpha_{\mathrm{S}_{1}} \mathrm{I}-\mathrm{CN}, \gamma-\mathrm{CN}$, and other $\beta$-CN fragments (f $\boldsymbol{\beta}$ CN) for group 2 (Figure 4B). Principal component 2 seems to discriminate samples according to different proteolysis products, especially within group 2. Results suggests that the presence of fragments $\alpha_{\mathrm{S}_{1}}-\mathrm{I}-\mathrm{CN}$, $\gamma-\mathrm{CN}$, and $\mathrm{f} \beta-\mathrm{CN}$ could be markers of "poor production practice" for PDO buffalo mozzarella, as all control 


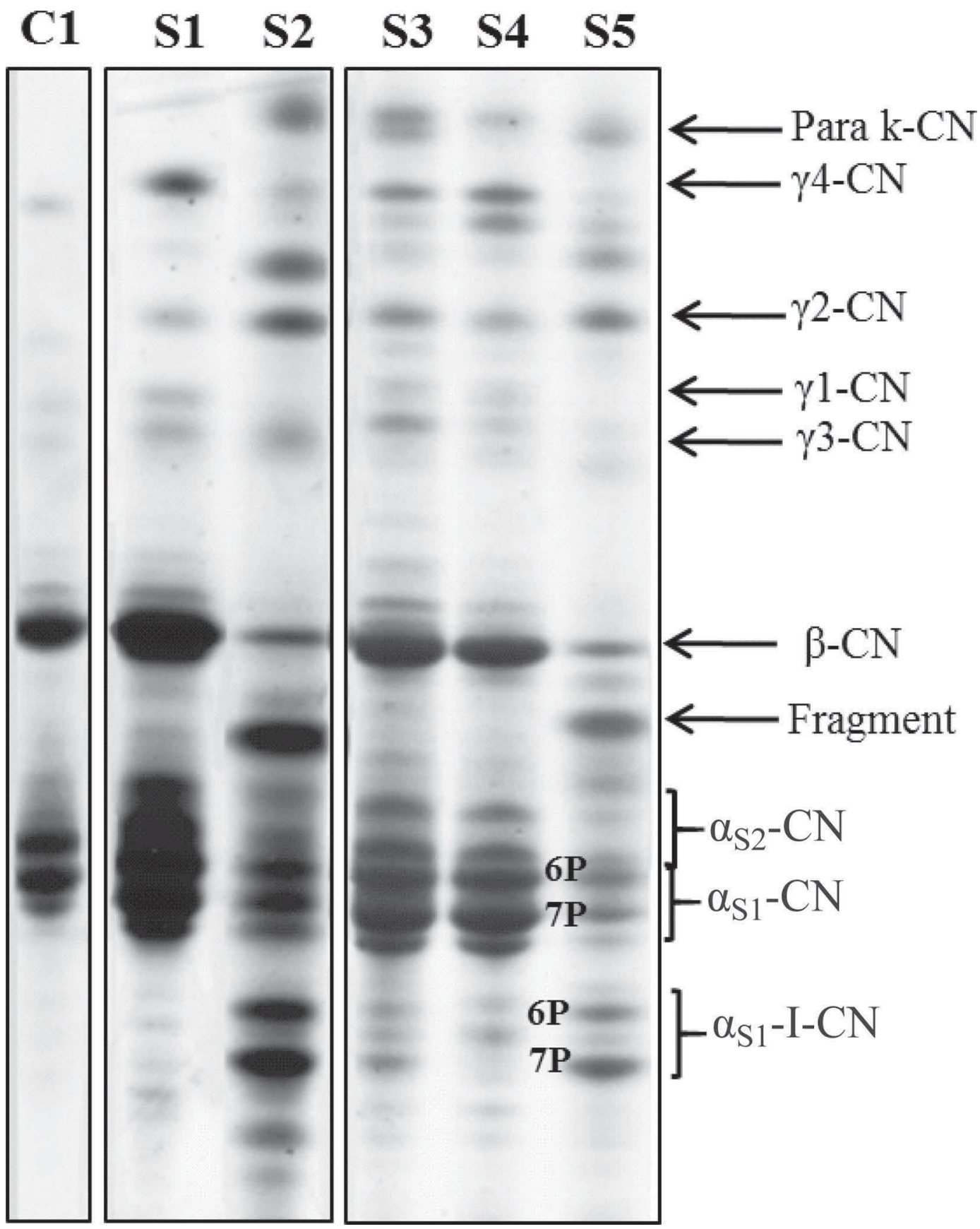

Figure 3. Urea-PAGE pattern of Protected Designation of Origin (PDO) buffalo mozzarella caseins. Lane C1 = fresh PDO buffalo mozzarella caseins; lanes S1 to S5 = caseins of samples S3 to S6 with different levels of proteolysis.

samples had a reduced amount or complete lack of these fragments.

\section{Proteolysis of Buffalo Milk $\alpha_{s 1}$-Casein by Rennet}

To assess whether the $\alpha_{\mathrm{S} 1} \mathrm{I}-\mathrm{CN}$ fragments originated from $\alpha_{S 1}$-casein, as a consequence of rennet activity, we carried out an in vitro hydrolysis of purified $\alpha_{S_{1}}$-casein. The kinetics reaction showed that $\alpha_{S_{1}}$-casein decreased with time and disappeared after $30 \mathrm{~min}$ (Figure 5). The $\alpha_{\mathrm{S} 1}-\mathrm{I}^{6 \mathrm{P}}$ and $\alpha_{\mathrm{S} 1}-\mathrm{I}^{7 \mathrm{P}}$ fragments were already formed by 15 min (lane 2 in Figure 5) and decreased with increasing time of rennet action, up to $2 \mathrm{~h}$, when they almost completely disappeared, whereas fragments of lower MW continued to increase. 

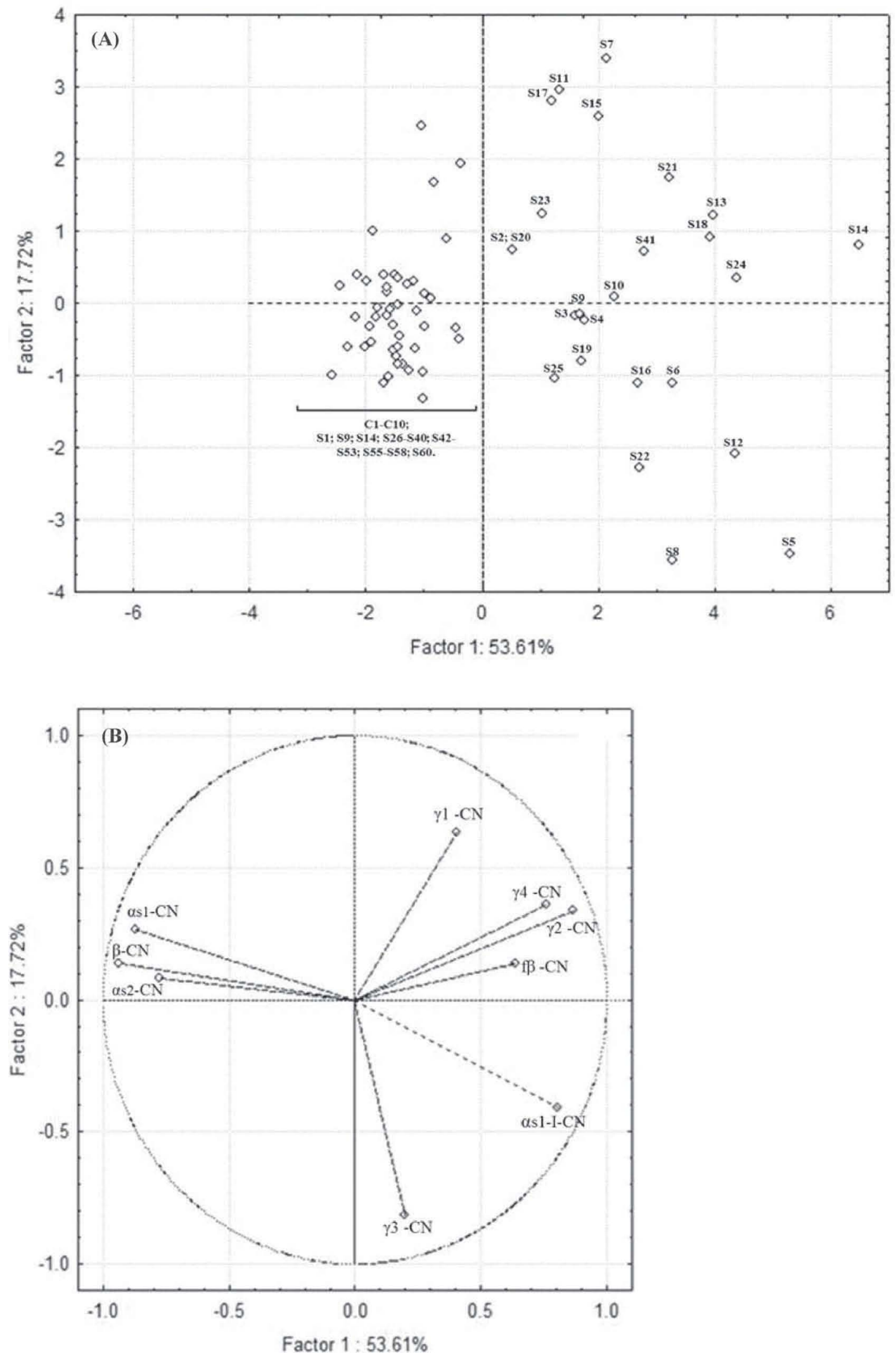

Figure 4. Principal component analysis biplots of urea-PAGE bands of 60 Protected Designation of Origin buffalo mozzarella samples (S) and 10 controls $(\mathrm{C})$. 
Results confirmed that the $\alpha_{\mathrm{S} 1}-\mathrm{I}^{6 \mathrm{P}}$ and $\alpha_{\mathrm{S} 1}-\mathrm{I}^{7 \mathrm{P}}$ fragments were derived from chymosin activity on $\alpha_{\mathrm{S} 1^{-}}$ casein and they were attributable to $\alpha_{S 1}-\mathrm{I}\left(\alpha_{S 1}\right.$ fragment 24-199). In analogy to bovine casein proteolysis, the other faster bands were sequentially formed by rennet action at $\mathrm{pH}$ 6.0; they were designated $\alpha_{\mathrm{S} 1}-\mathrm{II}^{6 \mathrm{P}}, \alpha_{\mathrm{S} 1}-\mathrm{II}^{7 \mathrm{P}}$, $\alpha_{\mathrm{S} 1}-\mathrm{III}^{6 \mathrm{P}}$, and $\alpha_{\mathrm{S} 1}-\mathrm{III}^{\mathrm{TP}}$ and attributed to the fragments $\alpha_{\mathrm{S} 1}-\mathrm{CN} \mathrm{f}(24 / 25-169)$ and $\alpha_{\mathrm{S}^{-}} \mathrm{CN} \mathrm{f}(24 / 25-149 / 150)$, respectively (Mulvihill and Fox, 1979). However, our observations in mozzarella cheese proteolysis were limited mainly to $\alpha_{\mathrm{S} 1}-\mathrm{I}^{6 \mathrm{P}}$ and $\alpha_{\mathrm{S} 1}-\mathrm{I}^{7 \mathrm{P}}$ due to denaturation

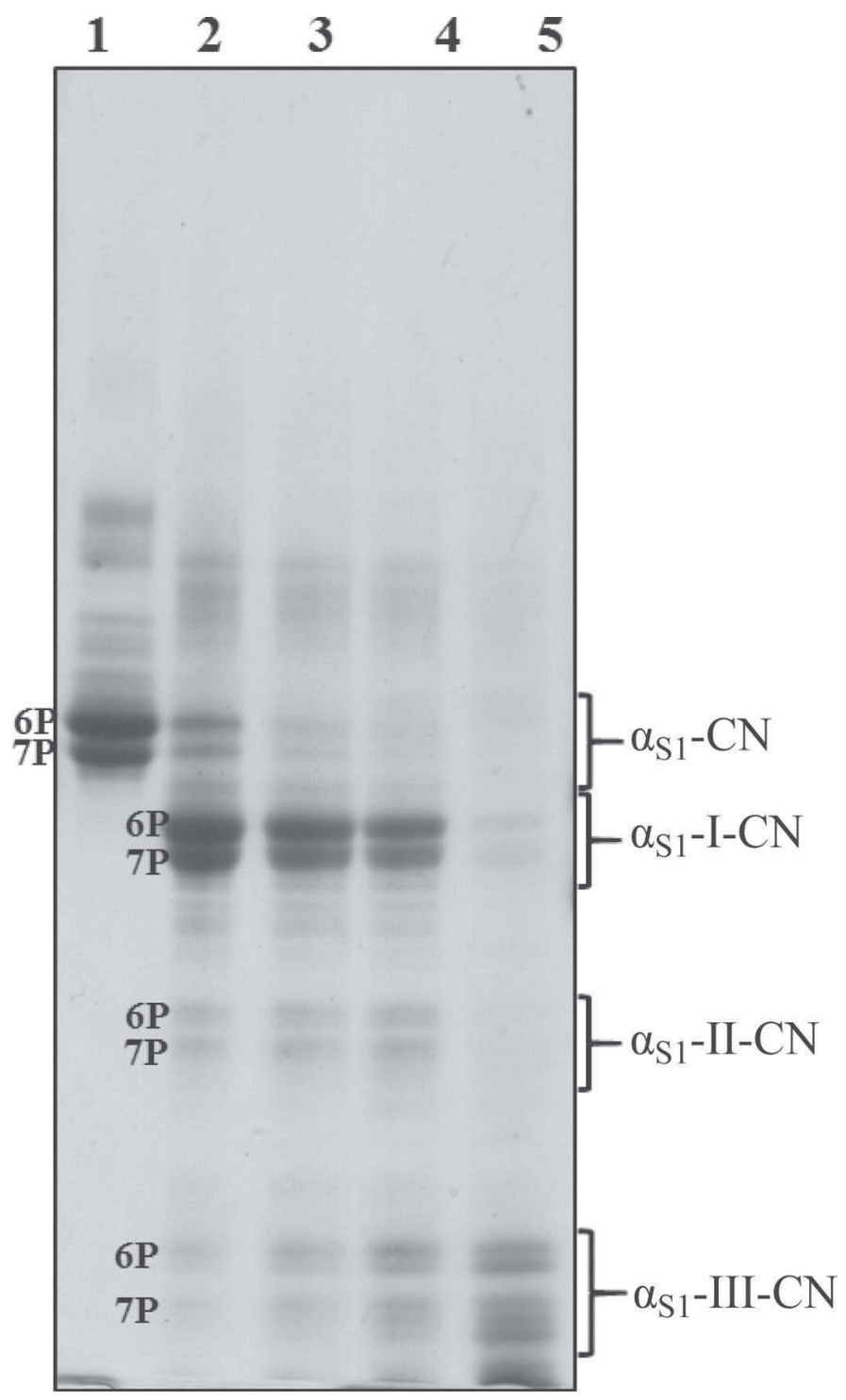

Figure 5. Urea-PAGE of buffalo $\alpha_{\mathrm{S} 1}$-casein hydrolyzed in vitro by the use of rennet. Lane $1=$ pure $\alpha_{\mathrm{S}^{-}}$CN of buffalo milk; lane $2=\alpha_{\mathrm{S}^{-}}$ $\mathrm{CN}$ of buffalo milk hydrolyzed by the use of rennet for $15 \mathrm{~min}$; lane 3 $=\alpha_{S 1}$ - CN of buffalo milk hydrolyzed by the use of rennet for $30 \mathrm{~min}$; lane $4=\alpha_{\mathrm{S}_{1}} \mathrm{CN}$ of buffalo milk hydrolyzed by the use of rennet for 60 min; lane $5=\alpha_{S 1}$ CN of buffalo milk hydrolyzed for $120 \mathrm{~min}$. of chymosin during the stretching phase at about $90^{\circ} \mathrm{C}$ (Hayes et al., 2002; Sheehan et al., 2007; Faccia et al., 2014).

\section{CONCLUSIONS}

This survey of river buffalo mozzarella cheeses by SDS-PAGE and urea-PAGE showed unusual hydrolysis. The proteolysis in this cheese generated a numbers of fragments identified by MS as derived from $\beta$ - and $\alpha_{\mathrm{S} 1}-\mathrm{CN}$. The presence of many of the fragments indicated that proteolysis in river buffalo mozzarella cheese occurred at different levels due to endogenous and exogenous enzymes during cheesemaking and storage. The proteolysis occurred at 2 different stages: (1) plasmin action progressively increased during long storage at room or low temperatures with increasing amounts of $\gamma$-CN and concomitant reduction of $\beta-\mathrm{CN}$; and (2) chymosin action increases s1-I-CN fragment in the curd until stretching, whereas it is slow or absent in cheese from stretching until consumption. Under normal conditions, the formation of the $\alpha_{\mathrm{S}_{1}} \mathrm{I}-\mathrm{CN}$ fragment is not detectable. Indeed, the intensity of the $\beta$ - and $\alpha_{\mathrm{s} 1}-\mathrm{CN}$ fragments in the finished product mainly depends on the storage and kind of raw matter. The proteomics approach we used allowed us to identify casein fragments to use as potential molecular markers. Finally, we can assert that SDS-PAGE revealed fragments from plasmin activity and its proteolysis rate, and alkaline ureaPAGE is better able to reveal fragments from chymosin action to use in the case of stored or pressed curd, a material usually imported as semi-finished product from other countries. The proposed methods can be useful to verify qualitatively the freshness of raw materials and conformity to PDO buffalo mozzarella, as is often required by the official protocol of production.

\section{ACKNOWLEDGMENTS}

The authors gratefully acknowledge the financial support from the "Consorzio per la Sperimentazione, Divulgazione e Applicazione delle Biotecniche Innovative (ConSDABI)" Piano Cappelle, 82100 Benevento, Italy, within the project "INNOVAGEN."

\section{REFERENCES}

Addeo, F., and J. C. Mercier. 1977. Primary structure of the casein macropeptide of kappa casein of buffalo. Biochimie 59:375-379.

Andrews, A. T. 1983. Proteinases in normal bovine milk and their action on caseins. J. Dairy Res. 50:45-55.

Barry, A. L. 1979. Reviews of the progress of dairy science: Enzymes of psychrotrophic bacteria and their effects on milk and milk products. J. Dairy Res. 46:573-588.

Baruzzi, F., R. Lagonigro, L. Quintieri, M. Morea, and L. Caputo. 2012. Occurrence of non-lactic acid bacteria populations involved 
in protein hydrolysis of coldstored high moisture Mozzarella cheese. Food Microbiol. 30:37-44.

Bonfatti, V., M. Gervaso, R. Rostellato, A. Coletta, and P. Carnier. 2013. Protein composition affects variation in coagulation properties of buffalo milk. J. Dairy Sci. 96:4182-4190.

Candiano, G., M. Bruschi, L. Musante, L. Santucci, G. M. Ghiggeri, B. Carnemolla, P. Orecchia, L. Zardi, and P. G. Righetti. 2004. Blue silver: A very sensitive colloidal Coomassie G-250 staining for proteome analysis. Electrophoresis 25:1327-1333.

Carles, C., and B. Ribadeau-Dumas. 1984. Kinetics of action of chymosin (rennin) on some peptide bonds of bovine $\beta$-casein. Biochemistry 23:6839-6843.

Carles, C., and B. Ribadeau-Dumas. 1985. Kinetics of action of chy-

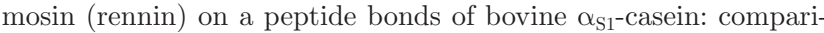
son of the behaviour of this substrate with that of $\beta$-casein and к-casein. FEBS Lett. 185:282-286.

Chianese, L., M. Quarto, F. Pizzolongo, M. G. Calabrese, S. Caira, R. Mauriello, S. De Pascale, and F. Addeo. 2009. Occurrence of genetic polymorphism at the $\alpha_{\mathrm{s} 1}$-casein locus in Mediterranean water buffalo milk. Int. Dairy J. 19:181-189.

Chikuni, K., Y. Mori, T. Tabata, M. Saito, M. Monma, and M. Kosugiyama. 1995. Molecular phylogeny based on the kappa-casein and cytochrome b sequences in the mammalian suborder ruminantia. J. Mol. Evol. 41:859-866.

Costabel, L., M. S. Pauletti, and E. Hynes. 2007. Proteolysis in mozzarella cheeses manufactured by different industrial processes. J. Dairy Sci. 90:2103-2112.

Creamer, L. K., and N. F. Olson. 1982. Rheological evaluation of maturing Cheddar cheese. J. Food Sci. 47:631-636, 646.

Dave, R. I., D. J. Mcmahon, C. J. Oberg, and J. R. Broadbent. 2003. Influence of coagulant level on proteolysis and functionality of mozzarella cheese made using direct acidification. J. Dairy Sci. 86:114-126.

De Jong, L. 1976. Protein breakdown in soft cheese and its relation to consistency. 1. Proteolysis and consistency of "Noordhollandse meshanger" cheese. Neth. Milk Dairy J. 30:242-253.

Di Luccia, A., G. Picariello, A. Trani, G. Alviti, P. Loizzo, M. Faccia, and F. Addeo. 2009. Occurrence of beta casein fragments in cold stored and curdled river buffalo (Bubalus bubalis L.) milk. J. Dairy Sci. 92:1319-1329.

Di Matteo, M., G. Chiovitti, and F. Addeo. 1982. Variation in the composition of Mozzarella cheese during storage. Sci. Tecn. Latt. Cas. 33:197-213

Eigel, W. N. 1977. Effect of bovine plasmin on $\alpha_{\mathrm{s} 1}-\mathrm{B}$ and $\beta$-A caseins. J. Dairy Sci. 60:1399-1403.

Eigel, W. N., J. E. Butler, C. A. Ernstrom, H. M. Farrell Jr., V. R. Harwalkar, R. Jenness, and R. M. Whitney. 1984. Nomenclature of proteins of cow's milk: Fifth revision. J. Dairy Sci. 67:1599-1631.

El-Shibiny, S., and M. H. Abd El-Salam. 1977. Action of milk clotting enzymes on $\alpha_{S}$-caseins from buffalo's and cow's milk. J. Dairy Sci. 60:1519-1521.

Everard, C. D., D. J. O'Callaghan, M. J. Mateo, M. Castillo, F. A. Payne, and C. P. O'Donnell. 2011. Effects of milk composition, stir-out time, and pressingduration on curd moisture and yield. J. Dairy Sci. 94:2673-2679.

Faccia, M., A. Trani, P. Loizzo, R. Gagliardi, B. La Gatta, and A. Di Luccia. 2014. Detection of $\alpha_{\mathrm{s} 1}-1$ casein in Mozzarella Fiordilatte: A possible tool to reveal the use of stored curd in cheesemaking. Food Contr. 42:101-108.

Farkye, N. Y., L. J. Kiely, R. D. Allhouse, and P. S. Kindstedt. 1991 Proteolysis in mozzarella cheese during refrigerated storage. J. Dairy Sci. 174:1433-1438.

Feeney, E. P., T. P. Guinee, and P. F. Fox. 2002. Effect of pH and calcium concentration on proteolysis in Mozzarella cheese. J. Dairy Sci. 85:1646-1654

Ferranti, P., A. Scaloni, S. Caira, L. Chianese, A. Malorni, and F. Addeo. 1998. The primary structure of water buffalo $\alpha_{\mathrm{s} 1^{-}}$and $\beta$-casein identification of phosphorylation sites and characterization of a novel $\beta$-casein variant. J. Protein Chem. 17:835-844.

Fox, P. F. 1989. Proteolysis during cheese manufacture and ripening. J. Dairy Sci. 72:1379-1400.
Fox, P. F., and P. L. H. McSweeney. 1996. Proteolysis in cheese during ripening. Food Rev. Int. 12:457-509.

Fox, P. F., T. K. Singh, and P. L. H. McSweeney. 1994. Proteolysis in cheese during ripening Pages 1-13 in Biochemistry of Milk Products. A. T. Andrews, and J. Varley, ed. Royal Society of Chemistry, Cambridge, UK.

Gagnaire, V., M. Piot, B. Camier, J. P. Vissers, and G. Jan. 2004. Survey of bacterial proteins released in cheese: A proteomic approach Int. J. Food Microbiol. 94:185-201.

Gaiaschi, A., B. Beretta, C. Poiesi, A. Conti, M. G. Giuffrida, C. L. Galli, and P. Restani. 2000. Proteolysis of as-casein as a marker of Grana Padano cheese ripening. J. Dairy Sci. 83:2733-2739.

Ganguli, N. C., O. P. Singhal, and V. R. Bhalerao. 1965. A comparative study on the release of peptides from buffalo and cow milk caseins by trypsin. Indian J. Biochem. 2:186-188.

Hayes, M. G., J. C. Oliveira, P. L. H. McSweeney, and A. L. Kelly 2002. Thermal inactivation of chymosin during cheese manufacture. J. Dairy Res. 69:269-279.

Hill, R. D., E. Lahav, and D. Givol. 1974. A rennin-sensitive bond in $\alpha_{\mathrm{S} 1}$-casein. J. Dairy Res. 41:147-153.

Hurley, M. J., L. B. Larsen, A. L. Kelly, and P. L. H. McSweeney 2000. The milk acid proteinase cathepsin D: A review. Int. Dairy J. 10:673-681.

Juillard, V., H. Laan, E. R. S. Kunji, M. Jeronimus-Stratingh, A. P. Bruins, and W. N. Konings. 1995. The extracellular P I-type proteinase of Lactococcus lactis hydrolyzes $\beta$-casein into more than one hundred different oligopeptides. J. Bacteriol. 177:3472-3478.

Kaminogawa, S., K. Yamauchi, S. Miyazawa, and Y. Koga. 1980. Degradation of casein components by acid protease of bovine milk. J. Dairy Sci. 63:701-704.

Kindstedt, P. S., C. M. Duthie, and J. K. Rippe. 1988. Rheological and proteolytic changes in Movarella cheese during refrigerated storage. J. Dairy Sci. 71(Suppl. 1):70. (Abstr.)

Law, B. A. 1979. Review of the progress of dairy science: Enzymes of psychrotropic bacteria and their effects on milk and milk produets. J. Dairy Res. 46:573-578.

Le Bars, D., and J. C. Gripon. 1989. Specificity of plasmin towards bovine $\alpha$ S2-casein. J. Dairy Res. 56:817-821.

Ledford, R. A., A. C. O'Sullivan, and K. R. Nath. 1966. Residual casein fractions in ripened cheese determined by polyacrylamide gel electrophoresis. J. Dairy Sci. 49:1098-1101.

Mamone, G., S. Caira, G. Garro, A. Nicolai, P. Ferranti, G. Picariello, A. Malorni, L. Chianese, and F. Addeo. 2003. Casein phosphoproteome: Identification of phosphoproteins by combined mass spectrometry and two-dimensional gel electrophoresis. Electrophoresis 24:2824-2837.

McGoldrick, M., and P. F. Fox. 1999. Intervarietal comparison of proteolysis in commercial cheese. Z. Lebensm. Unters. Forsch. 208:90-99.

McSweeney, P. L. H., N. F. Olson, P. F. Fox, A. Healy, and P. Hojrup. 1993. Proteolytic specificity of chymosin on bovine $\alpha_{s 1}$ casein. J. Dairy Res. 60:401-412.

Mulvihill, D. M., and P. F. Fox. 1979. Proteolytic specificity of chymosin on bovine $\alpha_{\mathrm{s} 1}$-casein. J. Dairy Res. 46:641-651.

Mulvihill, D. M., and A. McCarthy. 1993. Relationship between plasmin levels in rennet caseins and proteolytic and rheological changes on storage of cheese analogues made from these caseins. J. Dairy Res. 60:431-438.

Richardson, B. C. 1983. The proteinases of bovine milk and the effect of pasteurization on their activity. N.Z. J. Dairy Sci. Technol. 18:233-245.

Scherze, I., T. Sienkiewicz, and K. Krenkel. 1994. Untersuchungen zum proteolytischen abbau der Caseine. 2. Einfluß von Plasmin auf die Proteolyse im Goudakäse. Milchwissenschaft 49:564-569. [In German].

Sheehan, J. J., K. O'Sullivan, and T. P. Guinee. 2004. Effect of coagulant type and storage temperature on the functionality of reducedfat mozzarella cheese. Lait 84:551-566.

Sheehan, J. J., J. C. Oliveira, A. L. Kelly, and P. L. H. Mc Sweeney. 2007. Effect of cook temperature on primary proteolysis and pre- 
dicted residual chymosin activity of a semi-hard cheese manufactured using thermophilic cultures. Int. Dairy J. 17:826-834.

Sherry, S., N. Alkjaersig, and A. P. Fletcher. 1966. Activity of plasmin and streptokinase-activator on substituted arginine and lysine esters. Thromb. Diath. Haemorrh. 16:18-31.

Sienkiewicz, T., I. Scherze, and K. Krenkel. 1994. Untersuchungen zum proteolytischen abbau der Caseine. 1. Wirkung von Plasmin und Chymosin auf Caseine im Modell-System. Milchwissenschaft 49:499-504. [In German]

Somma, A., P. Ferranti, F. Addeo, R. Mauriello, and L. Chianese. 2008. Peptidomic approach based on combined capillary isoelectric focusing and mass spectrometry for the characterization of the plasmin primary products from bovine and water buffalo $\beta$-casein. J. Chromatogr. A 1192:294-300.

Sorhaug, T., and L. Stepaniak. 1997. Psychrotrophs and their enzymes in milk and dairy products: Quality aspects. Trends Food Sci. Technol. 8:35-41.

Sukla, S., T. K. Bhattacharya, R. T. Venkatachalapathy, P. Kumar, and A. Sharma. 2006. Cloning and characterization of $\alpha_{\mathrm{s} 2}$-casein gene of Riverine buffalo. DNA Seq. 17:458-464.
Swaisgood, H. E. 1992. Chemistry of the caseins. Pages 63-110 in Advanced Dairy Chemistry-I: Proteins. P. F. Fox, ed. Elsevier Applied Science, New York, NY.

Trieu-Cuot, P., and F. Addeo. 1981. Occurrence of gamma casein in buffalo milk. J. Dairy Res. 48:311-317.

Tunick, M. H., E. L. Malin, P. W. Smith, J. J. Shieh, B. C. Sullivan, and K. L. Mackey. 1993. Proteolysis and rheology of low fat and full fat mozzarella cheeses prepared from homogenized milk. J. Dairy Sci. 76:3621-3628.

Yun, J. J., D. M. Barbano, L. J. Kiely, and P. S. Kinstedt, 1995. Mozzarella cheese: Impact of rod:coccus ratio on composition, proteolysis, and functional properties. J. Dairy Sci. 78: 751-760.

Yun, J. J., L. J. Kiely, D. M. Barbano, and P. S. Kinstedt. 1993. Mozzarella cheese: Impact of cooking temperature on chemical composition, proteolysis and functional properties. J. Dairy Sci $76: 3664-3673$. 